\title{
Upaya Meningkatkan Hasil Belajar Fisika dengan menggunakan media PhET simulation pada kelas XI IPA 2 SMA Manba'ul Ullum
}

\author{
Waqidatul Qoiriyah \\ Jurusan Teknik Informatika, Fakultas Teknik, Universitas Islam Syekh Yusuf, Jl. Mulana Yusuf No.10 Tangerang \\ Banten 15118, Indonesia \\ wqoiriyah@unis.ac.id
}

\begin{abstract}
Abstrak. Penelitian ini bertujuan untuk meningkatkan hasil belajar fisika peserta didik kelas XI dengan menggunakan media PhET simulation. Jenis penelitian yang dilakukan yakni penelitian tindakan kelas dengan tiga siklus. Terdapat lima tahap dalam penelitian ini, antara lain tahap persiapan, tahap perencanaan, tahap pelaksanaan, tahap observasi dan monitoring, dan tahap refleksi. Terdapat dua jenis instrumen yang digunakan dalam penelitian yakni kuantitatif dan kualitatif. Instrumen Kuantitatif berupa kuesioner dan tes kemampuan akademik. Kuesioner siswa diberikan di setiap akhir siklus, kuesioner untuk guru diberikan di awal dan digunakan dalam menganalisis kebutuhan guru. Sedangkan instrument kualitatif melalui observasi pembelajaran, wawancara, catatan lapanagan dan analisis dokumentasi. Dengan subyek penelitian siswa berjumlah 36 siswa. Setelah siklus rata rata kelas menjadi 64,3 namun belum mencapai KKM sehingga dilakukan siklus II. Dari siklus kedua diperoleh rata-rata kelas sebesar 67,8 peningkatan ini juga belum memenuhi KKM sehingga dilakukan siklus keIII kemudian didapat nilai rata-rata kelas sebesar 77,5. Berdasarkan data tersebut dapat disimpulkan bahwa penggunaan media pembelajaran PhET simulation dapat meningkatkan hasil belajar siswa kelas XI IPA2 SMA Manba'ul Ullum.
\end{abstract}

Kata kunci: PhET Simulation, penelitian tindakan kelas, hasil belajar.

\begin{abstract}
This study aims to improve the physics learning outcomes of students of class XI using the PhET simulation media. The type of research conducted is classroom action research with three cycles. There are five stages in this research, including the preparation stage, the planning stage, the implementation phase, the observation and monitoring stage, and the reflection stage. There are two types of instruments used in research, namely quantitative and qualitative. Quantitative instruments in the form of questionnaires and academic ability tests. Student questionnaires are given at the end of each cycle, teacher questionnaires are given at the beginning and used in analyzing teacher needs. While the qualitative instrument through learning observation, interviews, learning notes and documentation analysis. With the research subjects students numbered 36 students. After the class average cycle becomes 64.3, it has not yet reached KKM so that the second cycle is carried out. From the second cycle, the class average of 67.8 was obtained, this increase also did not meet the KKM, so that in the second cycle, the average grade value was 77.5. Based on these data it can be concluded that the use of PhET simulation learning media can improve the learning outcomes of Manba'ul Ullum High School XI grade students.
\end{abstract}

Keywords: PhET Simulation, action research, learning outcomes.

\section{Pendahuluan}

Mata pelajaran fisika sudah diperkenalkan sejak siswa duduk di bangku sekolah menengah pertama bahkan sekolah dasar, beberapa siswa masih beranggapan mata pelajaran fisika adalah salah satu mata pelajaran yang sulit. Hal ini tidak di imbangi dengan kemampuan guru yang memadai, dimana beberapa guru beranggapan tugasnya hanya mentransfer pengetahuan yang dimiliki guru kepada siswa dengan target tersampaikannya topik-topik yang tertulis dalam dokumen kurikulum kepada siswa. Beberapa guru tidak memberi inspirasi kepada siswa dan tidak melatih siswa untuk hidup mandiri. Pelajaran yang disajikan guru kurang menantang siswa untuk berfikir. Akibatnya siswa tidak menyenangi pelajaran. Proses pembelajaran dikelas hanya guru yang mengerti. Kemudian kebanyakan pengawas dari dinas pendidikan belum berfungsi sebagai supervisor. Ketika pengawas datang beliau hanya memeriksa kelengkapan administrasi guru yang berupa program semester, program tahunan, dan administrasi lain seperti rencana pelaksanaan pembelajaran. Jarang sekali terdapat pengawas yang meninjau langsung kegiatan belajar mengajar dikelas. 


\section{Jurnal Keilmuan dan Aplikasi Teknik} UNISTEK, 2019, Vol. 6, No.1

\begin{abstract}
Demikian halnya dengan kepala sekolah, Kepala sekolah pada umumnya juga hanya mementingkan administrasi guru namun jarang melakukan observasi dan supervisi terhadap pembelajaran yang dilakukan guru. Akibatnya guru tidak tertantang melakukan persiapan mengajar dengan baik, mencari metoda yang tepat dan bervariasi, dan mempersiapkan bahan untuk percobaan di laboratorium. Semestinya semua pihak memperhatikan proses pembelajaran di dalam ruang kelas, dimana hasil belajar merupakan dampak dari proses pembelajaran. Proses pembelajaran yang baik seharusnya menghasilkan nilai tes atau hasil belajar yang baik pula. Paradigma yang hanya mementingkan hasil tes harus segera di ubah menjadi memeperhatikan proses pembelajaran. Oleh karena itu proses pembelajaran penting sekali dikemas sehingga menarik motivasi belajar siswa. Keterbatasan laboratorium seharusnya tidak menjadi hambatan pengembangan kreatifitas guru dalam mengemas sebuah pembelajaran. PhEt simulation merupakan salah satu media yang dapat digunakan guru untuk meningkatkan motivasi belajar siswa.

Menurut peneliti PhET simulation menjadi istimewa digunakan dalam membangun konsep belajar fisika yang sulit digambarkan dengan kata kata. Simulasi yang terdapat dalam media PhET dapat membangkitkan rasa ingin tahu siswa, untuk kemudian meningkatkan motivasi belajar yang berakhir pada peningkatan hasil belajar. Dalam sebuah pembelajaran proses evaluasi pembelajaran tidak kalah pentingnya dalam hal mengevaluasi. Proses evaluasi pembelajaran yang dimaksud disini adalah lesson study.
\end{abstract}

Lesson study dilakukkan secara kolaboratif oleh guru untuk membicarakan masalah dalam pembelajaran, menganalisis penyebabnya, dan mencari solusi untuk memecahkannya. Seseorang akan menjadi luar biasa jika dia mau menerima kritik yang bersifat membangun. Karena dilakukan secara kolaboratif model pembelajaran ini menurut peneliti akan saling menguntungkan karena akan terjadi pertukaran ilmu, wawasan, pengalaman dan masih banyak hal positiv lain. Sebelumnya kita perlu mengetahui bahwa lesson study bukanlah metoda atau strategi pembelajaran tetapi kegiatan lesson study dapat menerapkan berbagai metoda atau strategi pembelajaran yang sesuai dengan situasi, kondisi dan permasalahan yang dihadapi guru. Kegiatan lesson study pada dasarnya merupakan suatu kegiatan yang mampu mendorong terbentuknya sebuah komunitas belajar baik komunitas belajar di antara pelajar maupun pengajar.

Lesson study ini terdiri dari tiga tahapan, yaitu Plan (merencanakan), Do (melaksanakan) dan See (merefleksi). Selain beberapa hal yang telah disebutkan tahapan ini juga membuat peneliti menilai bahwa model pembelajaran lesson study ini istimewa. Melalui tahap plan atau perencanaan, guru merancang pembelajaran yang dapat membelajarkan siswa, dan membuat siswa berpartisipasi aktif dalam kegiatan belajar mengajar, perencanaan ini disusun oleh beberapa guru, kepala sekolah dan observer. Dalam hal ini guru menyiapkan modul PhET yang akan digunakan. Pada pelaksanaannya semua pihak bekerja, guru yang menjadi model akan di nilai efektifitas mengajarnya, dimana dalam tahap ini semua pihak (kepala sekolah, guru, dan observer) akan mengamati dengan jeli hal-hal yang terjadi di internal dan eksternal. Observer tidak akan menilai atau merefleksi kegiatan belajar mengajar namun observer disini lebih terfokus pada siswa, awalnya Kemudian tedapat tahap yang terakhir yaitu refleksi, dalam tahap ini guru mengawali diskusi dengn observer dan kepala sekolah, kemudian kepala sekolah mensupervisi semuanya dan memberikan masukan yg bersifat membangun. Pada tahap releksi jika dirasa perlu merubah modul pembelajaran dengan media PhET maka akan dilakukan perubahas sesuai kebutuhan siswa.

\section{Bahan dan Metode}

Jenis penelitian yang dilakukan adalah Penelitian Tindakan Kelas (PTK) dengan tiga siklus. Dengan subyek penelitian siswa kelas XI IPA 2 SMA Manba'ul ulum ASSHIDIQIYAH tahun pelajaran 2017/2018 yang berjumlah 36 siswa selama tiga bulan terhitung dari Februari 2017 hingga April 2018 pada materi teori kinetik gas dan termodinamika.

Terdapat dua jenis instrumen yang digunakan dalam penelitian yakni kuantitatif dan kualitatif. Kuantitatif dilakukan melalui instrumen berupa kuesioner dan tes kemampuan akademik. Kuesioner siswa diberikan di setiap akhir siklus, kuesioner untuk guru diberikan di awal dan digunakan dalam menganalisis kebutuhan guru. Sedangkan kualitatif dilakukan melalui observasi pembelajaran, wawancara, catatan lapanagan dan analisis dokumentasi. Observasi merupakan pengamatan yang dilakukan oleh observer dan penasehat. Catatan lapangan dilakukan oleh masing-masing peneliti, observer dan kepala sekolah (Sebagai supervisi).

\section{Hasil dan Pembahasan}

Berdasarkan penelitian yang telah dilakukan sejak bulan februari hingga april 2018, diperoleh data hasil belajar siswa sebagai berikut: Berdasarkan data pada hasil penelitian dapat disimpulkan bahwa pembelajaran dengan menggunakan media pembelajaran PhET simulation dapat meningkatkan hasil belajar fisika peserta didik, tidak hanya itu, motivasi, rasa ingin tahu, keaktifan siswa juga meningkat. Terbukti dari lembar catatan lapangan disebutkan bahwa siswa menjadi lebih sering maju ke depan dengan inisiatif mereka untuk mengerjakan soal yang diberikan guru juga dijelaskan dalam kalimat lain di lembar catatan lapangan mengenai antusias siswa dalam memperhatikan pelajaran hingga siswasiswa yang duduk dibagian belakang pindah ke bagian depan karena ingin lebih mengerti. Hal tersebut menunjukkan rasa ingin tahu siswa yang meningkat. 
Dalam setiap siklusnya akan diperoleh hasil belajar siswa dimana hasil belajar siswa di akhir siklus akan dibandingkan mulai dari sebelum tindakan, hingga ketiga siklus selesai. Keberhasilan penerapan model pembelajaran yang dilakukan juga dapat dilihat melalui kuesioner di akhir proses. Ketuntasan siswa dinyatakan berhasil apabila mencapai $75 \%$. Perhitungan hasil presentase hasil belajar siswa ialah sebagai berikut:

Dimana:

$$
K B=\frac{T}{T_{t}} \times 100
$$

$$
\begin{array}{ll}
\mathrm{KB} & =\text { Ketuntasan Belajar } \\
\mathrm{T} & =\text { Jumlah skor yang diperoleh siswa } \\
T_{t} & =\text { jumlah skor total }
\end{array}
$$

Upaya meningkatkan hasil belajar peserta didik dengan menggunakan media PhET simulation ini memang membuat banyak perubahan pada siswa, hal yang paling penting adalah meningkatnya nilai kognitif siswa yang jika digambarkan sebagai berikut:

Table 1. Perbandingan Hasil Evaluasi Siswa siklus

\begin{tabular}{cc}
1,2 dan 3 & \\
\hline Ketuntasan & Nilai Rata-Rata \\
\hline Siklus 1 & 64,3 \\
\hline Siklus 2 & 67,8 \\
\hline Siklus 3 & 77,5
\end{tabular}

Keterangan tabel merupakan hasil rata-rata kelas selama dilakukan tiga siklus dimana selalu terjadi peningkatan di setiap siklusnya hanya saja peningkatan tersebut tidak melebihi KKM yang ditetapkan yakni 75 shingga dilakukan siklus selanjutnya hingga target tercapai yakni 77,5.

\section{Kesimpulan}

Kegiatan pembelajaran dengan menggunakan media PhET mampu mendorong terbentuknya kelompok belajar diantara pelajar. Pengetahuan yang dibangun dapat menjadi modal sangat berharga untuk meningkatkan kualitas kinerja masing-masing pihak yang terlibat. Beberapa hal positif meningkat setelah diadakannya .

Pada siswa pembelajaran dengan menggunakan media pembelajaran PhET simulation dapat meningkatkan kualitas pembelajaran itu sendiri. Kualitas pembelajaran yang dimaksud adalah keaktifan siswa, motivasi siswa, interaksi siswa dan hasil belajar siswa pastinya terbukti dari nilai sebelum dan setelah siklus mengalami perbedaan yang cukup besar.

Sebelum siklus rata-rata kelas 62,8 setelah siklus satu menjadi 64,3 namun belum mencapai kriteria ketuntasan minimal sehingga diadakan siklus kedua dan rata-rata kelas menjadi 67,8 peningkatan ini juga belum memenuhi kriteria ketuntasan minimum sehingga dilakukan siklus tiga yang kemudian nilai rata-rata kelas menjadi 77,5 . Pada siklus tiga terlihat nilai rata-rata siswa telah melebihi kriteria ketuntasan minimum, sehingga tidak dilakukan siklus empat. Selain itu juga dikarenakan masalah yang dihadapi dirasa sudah terselesaikan.

\section{Daftar Pustaka}

Arsyad, A. (2014). Media Pembelajaran. Jakarta: PT RAJA GRAFINDO PERSADA.

Djaali. (2008). Psikologi Pendidikan. Jakarta: Bumi Aksara

Hamalik, O. (1994). Media Pendidikan, cetakan ke 7. Bandung : PT. Citra Aditya Bakti.

Hamzah. (2010). Teori Motivasi dan Pengukurannya: Analisis di Bidang Pendidikan. Jakarta: Bumi Aksara.

Indriana, D. (2011). Ragam Alat Bantu Media Pembelajaran. Yogyakarta: DIVA Press (Anggota IKAPI)

Iskandar. (2012). Psikologi Pendidikan (Sebuah Orientasi Baru). Jakarta: Gaung Persada Press Grup

Jamarnis, M. (2013). Orientasi Baru dalam Psikologi Pendidikan. Bogor: Ghalia Indinesia.

Kasimin, D. (2012). Media Pembelajaran : Teori dan Aplikasi (pertama ed.). yogyakarta: Trust Media Publishing.

Knight, Randall D. (2012). Physics For Scientists And Engineers. http://www.wilwy.com/go/permissions.

Kustandi, C. (2011). Media Pembelajaran Manual dan Digital. Bogor: Ghalia Indonesia.

Lestari, R. D. (2012). Penggunaan Alat-Alat Sederhana Dalam Pembelajaran Untuk Meningkatkan Aktivitas Prestasi Belajar Siswa. Prosiding Seminar Nasional Sains, 110.

Pribadi, B. A. (2011). Model assure untuk mendesain pembelajaran sukses. jakarta: Dian Rakyat.

Riduwan. (2005). Belajar Mudah Penelitian untuk Guru, Karyawan dan Peneliti Pemula. Bandung: Alfa Beta

Sadiman, dkk.(2014). Media Pendidikan.Jakarta: PT RajaGrafindo Persada

Setyosari, P. (2013). Metode Penelitian Pendidikan \& Pengembangan. Jakarta: Prenada Media Grup.

Smaldino, S. E. (2012). Instructional Technologi \& Media For learning (Teknologi Pembelajaran dan Media Untuk Belajar). jakarta: Kencana Prenanda Media Grup.

Sugiyono. (2015). Metode Penelitian \& Pengembangan Research and Development. Bandung: Alfabeta.

Suyanto. (2013). Menjadi Guru Profesional. Jakarta: Erlangga Grup.

Viajayani, E.R. (2013). Pengembangan Media Pembelajaran Fisika Menggunakan Macromedia Flash Pro 8 pada Pokok bahasan Suhu dan Kalor. jurnal UNS ISSN 2338 - 0691

Walker, J. (2007) Fundamental Of PHYSICS Halliday $\&$ Resnick. http://www.wilwy.com/go/permissions. 
Jurnal Keilmuan dan Aplikasi Teknik

UNISTEK, 2019, Vol. 6, No.1 